\title{
Game Preserve at Valeport Marsh
}

\section{by Dave Green, Regina}

Credit is due to the Wildlife Branch for the establishment of a permanent wildlife sanctuary at Valeport Marsh on the southern end of Last Mountain Lake.

The area, approximately one and one-half miles long by threequarters of a mile wide, lies to the southwest of the C.P.R. right of way and Highway No. 20, immediately south of Valeport, and is bounded on the south by the P.F.R.A. dam across the Qu'Appelle River. Posted as a game preesrve by conservation officers, the Valeport sanctuary includes pant of the wooded and rolling southwesit side of the valley, an extensive area of open water, and admirable cover for nesting in the form of bulrushes and shoreline sedge.

Among the conservation-conscious citizens who have worked for the establishment of the sanctuary is Athol Swieet of Craven, who has owned propenty to the west of the marsh for many years. Mr. Sweet particularly asked to have his land included in the preserve.

Thirty years ago the marsh was known as one of the finest nesting grounds in southern Canada. To discuss a programme to preserve the marsh and to restore it to its former bounty, a meeting was called at Craven in May of this year by conservation officers Ray Puddicombe and Peter Bergren. It was decided at the meeting that a "goose-seeding" project should be tried at the marsh, and in accordance with approved methods, approximately 100 young Canada Geese were transported to Valeport from the Wascana Waterfowl Park in Regina at banding time, July 6.

Since it is an observed fact that waterfowl have a tendency to return to the place from which they learn to fly, it is hoped that ensuing years will see an increase in the goose population at the marsh.

In addition to the geese, approximately 70 varieties of birds find sanctuary in the marsh. Waterfowl, wading birds, birds of prey and songbirds take shelter among the reeds or on the wooded hills nearby. The Valeport game presierve was esitablished for the protection, propagation and perpetuation of birds and animals. It will afford protection to migratory watierfowl along the flyways, and, with the co-operation of sportsmen and the public in general, should provide an admirable breeding ground where a goose population can be builit up to the benefit of the entire southeastern part of the province.

Sportsmen are particularly urged to refrain from shocting geese in the vicinity of the Valeport and Wasicana sanctuaries, where the birds have been raised under artificial conditions and are consequently unwary of predatory humans.

Future plinis for Valepont Marsh include an annual transplanting of geese from Wascana Waterfowl Park to the sanctuary for several years. Floating nests, constructed by the Saskatchewan Fish and Game League, will provide the honkers with safe, dry nesting sites, supplementing the natural nesting sites lccated on dikes, islands and shoreline.

Despite the successful build-up of birds in the Regina area, the natural proceiss of dispersion does not seem to be enough to assure a healthy diffushion of geese throughout southern Saskatchewan and present plans call for a successive transplanting of birds into suitable areas like the Valeport Marsh.

\section{CHRISTMAS BIRD COUNT 1960}

In your report, list the numbers of each species seen on the ONE BEST DAY between December 21 and January 1 . In addition, list other species (number of individuals and date seen) between December 21 and January 1.

\section{Send reports as soon as possible to}

Dr. STUART HOUSTON 2401 Hanover Ave., Saskatoon 